phosphorus upon the health of the operatives, and especially to its action in inducing necrosis of the upper and lower jaw-bones. The workpeople who suffered most were naturally those who came most in contact with the fumes-such as the men engaged in mixing the composition, those employed in dipping the splints, or the females who "boxed" the finished matches.

Nowadays the mixing is done under such conditions that the workmen are not much exposed to the fumes; but the dippers, who, when at work, stand over a heated "stone" or plate coated with the composition, are especially liable to be attacked. It does not seem to be certainly established how the necrosis is actually brought about. There is no doubt, however, that workers with carious teeth are soonest affected. Phosphorus as such would appear to have little action; indeed, it is highly amprobable that the so-called "fume" can contain any sensible quantity of the free element, and it has been surmised with good reason that it consists of the lower oxides of phosphorus, and in particular of phosphorus oxide, which, as shown by Thorpe and Tutton, is actually more volatile than phosphorus itself. In "boxing" it frequently happens that numbers of the matches ignite, and the air of the boxing-factory is occasionally charged with a considerable amount of these oxides of phosphorus, mixed with phosphoric oxide. The evil effect of these fumes may be minimised by efficient ventilation, and by cleanliness on the part of the operatives, combined with strict attention to the condition of the teeth. Whether, however, it can be altogether obviated by such measures remains to be seen.

The discovery of red phosphorus, in 1845 , by Schrötter, of Vienna, led to many attempts to employ it in place of the more volatile and more inflammable variety. Red, or, as it sometimes is erroneously called, amorphous phosphorus, is a micro-crystalline powder of properties very dissimilar to those of ordinary or yellow phosphorus. It can be handled with impunity, is practically non-volatile, does not oxidise at ordinary temperatures, and therefore emits no "fume." It is, moreover, non-poisonous, and no cases of necrosis have been known to attend its use. Inasmuch as it confers ready inflammability upon the igniting compositions with which splints may be tipped, its general employment might, it was thought, obviate all risk of the "lucifer disease." Igniting compositions containing red phosphorus were first tried in Germany in I850, and about the same time in this country by Dixon and Co., of Manchester, and by Bell and Black in London, but they were not altogether successful. The matches were difficult to strike, and the ignition was almost explosive in character.

These disadvantages are not by any means insuperable; excellent matches of the kind were seen in the Paris Exhibition of 1867 , and again in the Vienna Exhibition of 1873 . Hochstetter, of Frankfort, manufactures matches containing red phosphorus, which are said to be cheaper than ordinary matches; they burn quietly, and may be ignited even on a cloth surface.

The "safety" matches which, in this country, are usually associated with the names of Bryant and May, were originally suggested by the late Prof. Böttger, and were first made by Lundstrom, of Jönköping, in 1855 . In this match the splint, according to Lundstrom's original patent, was dipped in a composition consisting of antimony sulphide, potassium chlorate and glue, and was ignited by rubbing against a specially prepared surface consisting of a mixture of red phosphorus, antimony sulphide and glue. Other varieties of the same kind of match contain in addition potassium bichromate, ferric oxide, minium, or manganese oxide. The amonnt of the red phosphorus needed to ignite these matches is extremely small, less than one fivethousandth of a grain being, it is said, sufficient. In fact it is possible to inflame many of them without any phosphorus at all, especially when they are rubbed against a smooth surface such as that of glass or paper. These facts make it hopeful that before very long the dreaded lucifer disease may be a thing of the past.
There is, indeed, no longer any valid reason why it should be allowed to exist. Yellow phosphorus is not essential to the manufacture of a lucifer match. If phosphorus in any form is required, it need only be in the form of the innocuous red variety-even for a "strike anywhere" match. Red phosphorus matches are rapidly gaining ground all over the Continent, and the day will probably come when this country will range itself with Denmark and Switzerland, and prohibit the use of all matches containing ordinary phosphorus.

\section{GERMAN DEEP-SEA EXPEDITION IN THE} STEAMSHIP "VALDIVIA."

THIS expedition was planned by Prof. Chun, or Leipzig, and was originally intended to be exclusively zoological, but, on the representation of Prof. Ratzel, physical and chemical researches were included in the programme. During last winter the German Parliament voted a sum of 300,000 marks to cover the expenses of the expedition, and further sums will probably be voted for the same purpose, and for the publication of the results.

The steamship Valdivia was some time ago chartered from the Hamburg-American Line, and has been fitted up with bacteriological, chemical, and biological laboratories, as well as with instruments for sounding, taking temperatures and samples of deep-sea waters, and for dredging, trawling, and the working of plankton nets at various depths. The Valdivia is a ship of 2600 tons gross, has a length of 320 feet, a width of 43 feet, and an indicated power of 1250 horses. She is thus as large as, if not larger than, H.M.S. Challenger. Captain Krech, a well-known commander of the Hamburg-American Line, has been selected to take command of the expedition, with eight officers and engineers and thirty-five of a crew; most of the officers have previously served under Captain Krech. The Valdivia steams from ten to eleven knots, and at the outset of the expedition had on board 2400 tons of coal, consisting chiefly of briquettes.

The laboratories and workrooms on board the Valdivia are more commodious and better fitted up with apparatus for scientific investigation than in any previous expedition of the kind, and the same may be said with respect to the various deck appliances for carrying on the deep-sea observations. Besides there is almost a superabundance of room for the storage of all the specimens that may be collected either at sea or on land. The cabins of the scientific staff are handsome and roomy, and the large cabin is supplied with a most magnificent scientific library, including a complete set of the Reports on the Scientific Results of the Challengrer Expedition. According to arrangement, the ship is to be provisioned, and all the other expenses of the expedition are to be defrayed by the Company for the sum of 340,000
marks. The table of the scientific staff and officers is to be supplied with wine at cost price. The members of the scientific staff receive eight marks each per day from Government, and their lives are insured for 30,000 marks each in case of death.

The scientific staff of the expedition is as follows :Official Members.

(1) Prof. Carl Chun (Leipzig), Leader.

(2) Prof. Schimper (Bonn a/Rh.), Botanist.

(3) Dr. Apstein (Kiel), Zoologist.

(4) Dr. Vanhöffen (Kiel), Zoologist.

(5) Dr. Braem (Breslau), Zoologist.

(6) Dr. G. Schott (Hamburg Seewarte), Oceanographer.

(7) Dr. P. Schmidt (Leipzig), Chemist.

(8) Officer Sachse (Hamb.-Amer. Line), Navigator.

(9) Dr. Bachmann (Breslau), Physician and Bacteriologist.

NO. I 502 , VOL. 58] 


\section{Non-official Members.}

(10) Dr. Brauer (Marburg a/L.), Zoologist.

(II) Dr. zur Strassen (Leipzig), Zoologist.

(I2) Herr F. Winter (Frankfurt a/M.), Scientific Draughtsman and Photographer.

It is proposed to divide the voyage into three periods :-

I. From Hamburg round the north of Scotland, passing the Cape de Verdes to Cape Town, for which roo days is estimated, Cape Town being reached in the second half of November.

II. From Cape Town, including an examination of the Agulhas Bank and the deep waters to the south, then southwards to the edge of Antarctic ice, returning northwards through the centre of the Indian Ocean to Coccos and Christmas Island and to Padang.

III. From Padang to Ceylon, Chagos, Seychelle, and Amirante Islands, to Zanzibar. Then home by Socotra, the Red Sea and the Mediterranean, Hamburg being reached early in June next year.

On August I the Valdivia left Hamburg, and was accompanied as far as Cuxhaven by Staats-Secretär von Posadowsky (the Burgomaster of Hamburg), the Directors of the Hamburg-American Line, Prof. Neumayer (Director of the Deutsche Seewarte), and many scientific men. In wishing success to the expedition, the German Minister dwelt upon the importance of a great State like Germany undertaking work of purely scientific character, such as that in which the members of the expedition were to be engaged; although no practical outcome was at present visible from researches of the kind, still the acquisition of new knowledge was, he held, one of the first duties of the State. The Chairman of the Directors of the Hamburg-American Line mentioned in his speech that the Directors considered it a privilege to be able to encourage scientific work; the Company had spared no pains in fitting up the ship and providing it with capable officers, and they expected to lose rather than to make money by the contract that had been entered into.

The ship left Cuxhaven at 8 p.m. on August I, and during the 2 nd and 3 rd the dredging and some of the other apparatus were tried for the first time with great success. On the evening of the 3 rd she anchored in the Firth of Forth, off Granton, for the purpose of taking on board some additional apparatus, and to permit the members of the expedition to examine the Challenger specimens of deep-sea deposits, as well as to land Dr. von Drygalski (who has been nominated as the scientific leader of the German South Polar Expedition of 1900), Dr. Pfeffer (of the Hamburg Museum), and Sir John Murray, who had accompanied the Valdivia from Hamburg. The members of the expedition were entertained at dinner in Edinburgh on the afternoon of the 4th, and in the evening the ship sailed again for the Faroe Channel. Geheimrath Dr. Mikulicz, professor of surgery in Breslau, joined the expedition at Edinburgh, and will accompany it as far as the Canaries.

\section{THROUGH UNKNOWN TIBET. ${ }^{1}$}

UTIL a little more than thirty years ago our knowledge of the Tibetan plateau-one of the most remarkable areas on the earth's surface-was exceedingly small, and was very much the same as it had remained since the journeys of Manning and Bogle in the last century. About $\mathrm{r} 865$, natives of India trained by the officers of the Great Trigonometrical Survey were employed in the exploration of portions of Central Asia inaccessible to Europeans; and in the course of the next ten to fifteen years great additions to our knowledge of Southern Tibet and of the trade routes leading to Lhasa from various directions were made by several intelligent and

1 By M. S. Wellby, Captain 18th Hussars. Pp. xiv +440 . (London T. Fisher Unwin, 1898 .)

$$
\text { NO. I } 502 \text {, VOL. } 58 \text { ] }
$$

enterprising men, especially those known as Nain Singh, A.K., and the Mirza. A series of Russian explorations begun by Przevalski in 1870 , continued by him for many years, and further prosecuted after his death by Pevtsof and others, added to our maps the main features of the Northern Tibetan escarpment, whilst considerable additions were made from time to time by Carey, Bonvalot and Prince Henry of Orleans, Rockhill, and other travellers; but still an immense area in the north-western part of the plateau was completely unexplored until i 891 . This, the highest part of Tibet, extends at least 600 miles from east to west, and 250 to 300 from north to south; and very little, if any, of its surface is less than 16,000 feet above the sea-level. It is intersected by snow-bearing ranges of mountains, and dotted over witk. numerous lakes, many of which are salt.

This bleak and barren region is known as the Chang or Chang-tung, and is a wilderness inhabited solely by

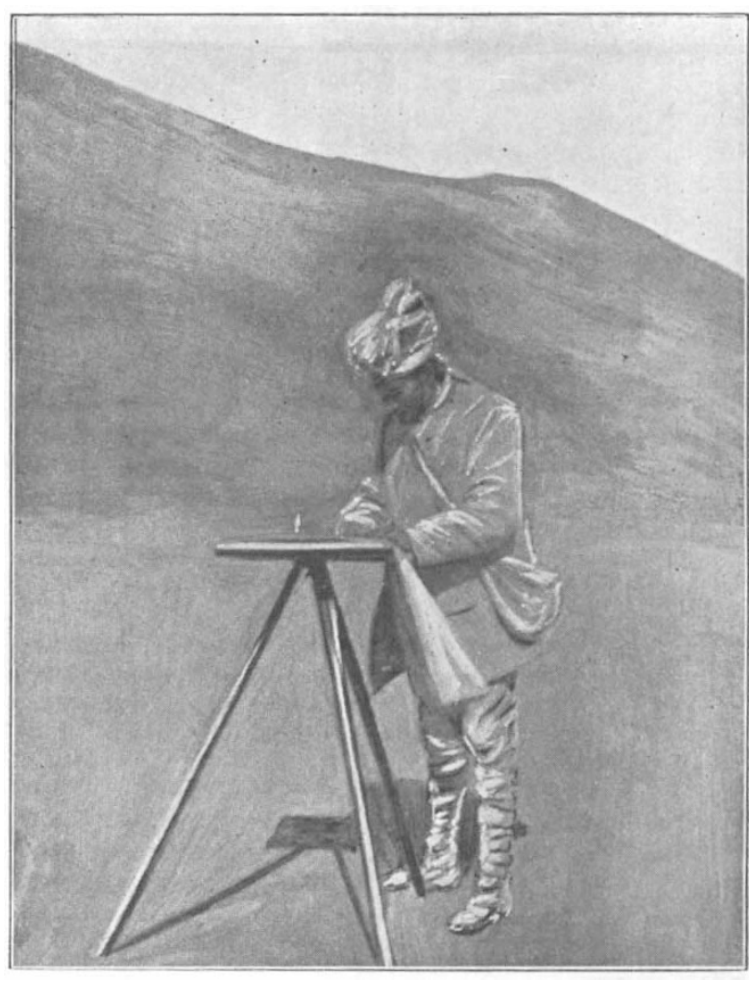

Surveying.

wild animals. A few nomads drive their flocks and herds to the lower and more grassy tracts on the border of the high plateau for pasture during the summer, but they appear never to visit the greater part of the area. Here is the especial home of the Tibetan antelope and the wild yak, at all events in the summer.

In 1874-75 a traverse of the plateau from Ladak to Tengri Nor and Lhasa was mapped by Nain Singh; but the region then examined lies at a somewhat lower elevation than the area to the northward, and the latter was first crossed from west to east by Bower and Thorold in I89I. Their route across the Chang, except in the neighbourhood of the Ladak frontier, lay south of the 34 th parallel, still leaving a broad area, marked as "unexplored" on the Royal Geographical Society's Map of Tibet, published in 1894, between the 34th parallel and the Kuenlun. Part of this country was crossed from north to south by Littledale in 1895 , in his attempt to reach Lhasa from the northward, his route 